\title{
BUDGETARY GOAL CHARACTERISTICS DAN TRANSPARANSI SERTA PENGARUHNYA TERHADAP KINERJA ANGGARAN DAN KINERJA MANAJERIAL
}

\author{
Luh Komang Merawati \\ Universitas Mahasaraswati Denpasar, email: mettamera@gmail.com
}

\begin{abstract}
Budget performance and managerial performance in public sector has been public concern and much noticed by the public since they are closely related to the aspects of public accountability. Achievement of budget performance and managerial performance is determined by the level of transparency and budgetary goal characteristics which consists of indicators of budgetary participation, difficulty in budget goals, budget feedback, budget evaluation and difficulty in budget goals.

This research was conducted to examine the effect of budgetary goal characteristics and transparency on budget performance and managerial performance in the Housing, Settlement and Land Agency (DPKPP) of Denpasar City, Bali Province. The data collection method used is by distributing questionnaires and obtained as many as 51 respondents as samples based on purposive sampling technique. The data analysis technique uses Partial Least Square analysis.

The results showed that the budgetary goal characteristics did not affect budget performance, the budgetary goal characteristics had a positive effect on managerial performance, transparency had a positive effect on budget performance, while transparency had a negative effect on managerial performance in DPKPP Denpasar.
\end{abstract}

Keywords: Budgetary Goal Characteristics, Transparency, Budget Performance, Managerial Performance

\section{PENDAHULUAN}

Anggaran merupakan suatu pernyataan mengenai estimasi kinerja yang hendak dicapai selama periode waktu tertentu yang dinyatakan dalam ukuran finansial (Mardiasmo,2009:61) sedangkan penganggaran adalah proses atau metode untuk mempersiapkan suatu anggaran. Penganggaran terkait dengan proses penentuan jumlah alokasi dana untuk tiap-tiap program dan aktivitas dalam satuan moneter, prosesnya dimulai ketika perumusan strategi dan perencanaan strategik telah selesai dilakukan. Terdapat tiga aspek yang tercakup dalam anggaran yaitu aspek perencanaan, aspek pengendalian dan aspek akuntabilitas publik (Satya, 2013). Pengawasan terhadap proses 
penganggaran harus diawasi mulai tahap perencanaan, pelaksanaan dan pelaporan. Istiyani (2009) juga menyatakan bahwa proses anggaran seharusnya diawali dengan penetapan tujuan, target dan kebijakan. Adanya kesamaan persepsi antar berbagai pihak tentang apa yang akan dicapai dan keterkaitan tujuan dengan berbagai program yang akan dilakukan, sangat krusial bagi kesuksesan anggaran. Kenis (1979) menjelaskan ada lima karakteristik tujuan anggaran (budgetary goal characteristics) yaitu partisipasi penyusunan anggaran, kesulitan tujuan anggaran, umpan balik anggaran, evaluasi anggaran dan kesulitan tujuan anggaran. Penerapan karakteristik tujuan anggaran dalam suatu kinerja anggaran diharapkan dapat mencapai tujuan anggaran yang telah ditetapkan oleh pemerintah karena anggaran dapat berjalan sesuai fungsi dan tujuannya. Dalam hal ini penerapan karakteristik tujuan anggaran yang terstruktur akan membantu mengidentifikasi lebih jelas siapa yang ikut berpartisipasi dalam anggaran, apa tujuan dari anggaran tersebut, kesulitan yang mungkin ditemui dalam anggaran, umpan balik yang diterima saat proses penganggaran dan peningkatan kinerja saat evaluasi anggaran, sehingga menunjang keberhasilan pemerintah dalam perencanaan dan pengelolaan kinerja anggaran.

Menurut Bastian (2006:171), anggaran kinerja adalah sistem penganggaran yang berorientasi pada output organisasi dan berkaitan sangat erat dengan visi, misi, dan rencana organisasi. Pelaksanaan anggaran dapat berjalan secara efektif apabila perencanaan dan penerapannya yang dalam hal ini kegiatan mengelola anggaran tersebut memperhatikan lima komponen budgetary goal characteristiscs (karakteristik tujuan anggaran) yaitu: partisipasi anggaran, kejelasan tujuan anggaran, evaluasi anggaran, umpan balik anggaran dan kesulitan tujuan anggaran (Milayanti dan Kholmi, 2012)

Di sisi lain, karakteristik tujuan anggaran juga memiliki pengaruh terhadap kinerja manajerial. Kinerja manajerial adalah kinerja individu anggota organisasi dalam kegiatan- 
kegiatan manajerial antara lain: perencanaan, investigasi, koordinasi, pengaturan staf, negosiasi, dan lain-lain. Semakin konsisten suatu organisasi menerapkan karakteristik tujuan anggaran, maka semakin baik kinerja manajerial suatu organisasi dan mempermudah organisasi dalam pencapaian tujuan anggaran karena dapat mempertimbangkan kebijakan-kebijakan dalam suatu proses anggaran. Munawar dkk. (2006) menemukan bahwa karakteristik tujuan anggaran berpengaruh secara signifikan terhadap perilaku, sikap dan kinerja aparat pemerintah daerah karena karakteristik tujuan anggaran dapat meningkatkan efektifitas kerja aparat pemerintah daerah di Kabupaten Kupang. Khotimah (2011) menemukan bahwa karakteristik tujuan anggaran berpengaruh terhadap kinerja manajerial SKPD dan komitmen organisasi berpengaruh dalam hubungan antara karakteristik tujuan anggaran dengan kinerja manajerial SKPD karena semakin tinggi karakteristik tujuan anggaran maka semakin tinggi kinerja manajerial SKPD.

Aspek transparansi dalam kinerja anggaran dan kinerja manajerial juga sangat penting untuk menghasilkan anggaran yang jelas dan sesuai dengan yang diharapkan. Menurut Mardiasmo (2009:45), transparansi adalah keterbukaan pemerintah dalam memberikan informasi yang terkait dengan aktifitas pengelolaan sumber daya publik kepada pihak yang membutuhkan yaitu masyarakat. Anugriani (2014) menemukan bahwa transparansi berpengaruh positif terhadap kinerja anggaran, artinya anggaran harus menyajikan informasi yang jelas mengenai tujuan, sasaran, hasil, dan manfaat yang diperoleh masyarakat dari suatu kegiatan atau proyek yang dianggarkan. Lismawati, dkk. (2013) menemukan bahwa transparansi pengelolaan keuangan berpengaruh positif dan signifikan terhadap kinerja SKPD Provinsi Bengkulu.

Penelitian ini dilakukan untuk menguji pengaruh karakteristik tujuan anggaran dan transparansi terhadap kinerja anggaran dan kinerja manajerial pada Dinas Perumahan, 
Kawasan Permukiman dan Pertanahan (DPKPP) Kota Denpasar Provinsi Bali yang merupakan satu satuan kerja perangkat daerah yang mempunyai tugas melaksanakan program dan kegiatan pembangunan. Kinerja anggaran dan kinerja manajerial pada DPKPP Kota Denpasar menjadi menarik untuk diteliti karena memiliki fungsi dan tugas menata ruang kota yang nyaman, sarana utilitas umum dan pertamanan untuk mewujudkan keindahan kota Denpasar.

Menurut Jensen dan Meckling (1976) teori agensi adalah hubungan keagenan sebagai sebuah kontrak dimana satu atau lebih (principal) menyewa orang lain (agent) untuk melakukan beberapa jasa untuk kepentingan mereka dengan mendelegasikan beberapa wewenang pembuatan keputusan kepada agen. Sesotyaningtyas (2012) menyebutkan bahwa teori keagenan ini telah dipraktekkan pada sektor publik, termasuk pemerintah daerah di Indonesia. Dalam proses penyusunan dan perubahan anggaran daerah, ada dua perspektif yang dapat ditelaah dalam aplikasi teori keagenan, yaitu hubungan antara eksekutif dengan legislatif, dan legislatif dengan pemilih (voter) atau rakyat. Implikasi penerapan teori keagenan dapat menimbulkan hal positif dalam bentuk efisiensi, tetapi lebih banyak yang menimbulkan hal negatif dalam bentuk perilaku opportunistik (opportunistic behaviour).

Konflik yang disebabkan perbedaan kepentingan dimana agen tidak memaksimalkan kinerja untuk kesejahteraan prinsipal tetapi lebih cenderung mementingkan kepentingan diri sendiri dengan cara mengabaikan kepentingan pemilik. Publik seringkali tidak puas dengan hasil kinerja yang dilakukan oleh pemerintah daerah, sedangkan pemerintah daerah selaku agen lebih mementingkan kesejahteraan sendiri. Oleh karena itu pemerintah daerah diwajibkan untuk melaporkan kinerjanya melalui laporan keuangan setiap periodenya 
Penganggaran dan kinerja memiliki keterkaitan dengan teori agensi karena penerapan teori agensi pada sektor publik yaitu pada proses penyusunan dan perubahan anggaran daerah. Hal ini terjadi karena pihak agensi memiliki informasi keuangan daripada pihak prinsipal (keunggulan informasi), sedangkan dari pihak prinsipal boleh jadi memanfaatkan kepentingan pribadi atau golongannya sendiri (self-interest) karena memiliki keunggulan kekuasaan (discretionary power). Maka dari itu diperlukan pelaporan kinerja dari pemerintah daerah selaku agen untuk mempertanggung jawabkan wewenang yang telah diberikan oleh masyarakat.

Karakteristik tujuan anggaran yang mencakup lima kriteria yaitu: partisipasi penyusunan anggaran, kejelasan tujuan anggaran, umpan balik anggaran, evaluasi anggaran dan kesulitan tujuan anggaran dapat meningkatkan efektifitas dalam kinerja anggaran dan meningkatkan efektifitas manajerial yang dalam hal ini adalah pemerintah dalam pengambilan keputusan. Tercapainya suatu kinerja anggaran yang baik tidak terlepas dari unsur karakteristik tujuan anggaran yaitu partisipasi penyusunan anggaran. Satya (2013) menemukan bahwa partisipasi staf berpengaruh positif terhadap penyusunan rencana kerja anggaran, karena adanya partisipasi staf dalam penyusunan anggaran seperti memberikan informasi, masukan pendapat, mengawasi dan dengan sigap, melakukan revisi jika terjadi kesalahan dapat meningkatkan penyusunan rencana kerja anggaran. Munawar, dkk. (2006) menemukan bahwa karakteristik tujuan berpengaruh terhadap perilaku, sikap, dan kinerja aparat pemerintah daerah Kabupaten Kupang dalam menyusun anggaran, melaksanakan anggaran, dan pertanggungjawaban anggaran.

Lismawati dan Auditya. (2013) menemukan bahwa akuntabilitas pengelolaan keuangan berpengaruh positif dan signifikan terhadap kinerja SKPD Provinsi Bengkulu. Hal tersebut menunjukkan bahwa semakin akuntabel pengelolaan keuangan dan pelaporan 
keuangan dalam SKPD Pemerintah Provinsi Bengkulu, maka akan semakin meningkatkan kinerja. Akuntabilitas tinggi pada pengelolaan keuangan diharapkan bisa meningkatkan kepercayaan masyarakat terhadap pemerintah sehingga dapat menciptakan iklim investasi yang baik. Istiyani (2009) dan Khotimah (2011) membuktikan bahwa empat karakteristik tujuan anggaran yaitu partisipasi penyusunan anggaran, kejelasan tujuan anggaran, umpan balik anggaran dan kesulitan tujuan anggaran berpengaruh positif terhadap kinerja manajerial pemerintah daerah.

Oleh karena itu hipotesis pertama dan hipotesis kedua dirumuskan sebagai berikut:

\section{$H_{1}$ : Karakteristik tujuan anggaran berpengaruh positif terhadap kinerja anggaran.}

\section{H2: Karakteristik tujuan anggaran berpengaruh positif terhadap kinerja manajerial.}

Transparansi adalah keterbukaan atas semua tindakan yang diambil oleh pemerintah. Prinsip transparansi menciptakan kepercayaan timbal balik antara pemerintah dan masyarakat melalui penyediaan dan menjamin kemudahan memperoleh informasi. Transparansi sangat berpengaruh dalam kinerja anggaran karena aspek transparansi dapat mempermudah masyarakat memperoleh informasi tentang kinerja anggaran. Transparansi akan memberikan dampak positif dalam tata pemerintahan karena pertanggung jawaban para perumus kebijakan sehingga kontrol masyarakat terhadap para pemegang otoritas pembuat kebijakan akan berjalan efektif.

Rahmawati (2013) menemukan bahwa transparansi kebijakan publik berpengaruh signifikan terhadap pengawasan keuangan daerah di Kabupaten Sukoharjo. Penelitian tersebut menunjukkan bahwa transparansi dibangun atas dasar arus informasi yang bebas, seluruh proses pemerintahan, lembaga-lembaga dan informasi perlu diakses oleh pihakpihak yang berkepentingan dan informasi yang tersedia harus memadai agar dapat dimengerti dan dipantau. Di sisi lain transparansi juga dibuktikan berpengaruh positif dan 
signifikan terhadap anggaran berkonsep value for money karena anggaran harus menyajikan informasi yang jelas mengenai tujuan, sasaran, hasil, dan manfaat yang diperoleh masyarakat dari suatu kegiatan atau proyek yang dianggarkan (Anugriani, 2014 dan Wandari, dkk., 2015)

Aji (2011) menemukan bahwa transparansi berpengaruh positif terhadap kinerja manajerial SKPD di Kabupaten Wonosobo. Penelitian tersebut menunjukan bahwa untuk meningkatkan transparansi kebijakan publik dapat dilakukan melalui penggunaan teknologi, karena dengan penggunaan teknologi masyarakat dapat dengan mudah mengakses informasi kebijakan publik. Lismawati dan Auditya. (2013) menemukan bahwa transparansi pengelolaan keuangan berpengaruh positif dan signifikan terhadap kinerja manajerial SKPD Provinsi Bengkulu.

Oleh karena itu hipotesis ketiga dan keempat dirumuskan sebagai berikut:

\section{H3: Transparansi berpengaruh positif terhadap kinerja anggaran.}

\section{H4: Transparansi berpengaruh positif terhadap kinerja manajerial.}

\section{METODE PENELITIAN}

Penelitian ini dilakukan di Dinas Perumahan, Kawasan Permukiman dan Pertanahan Kota Denpasar. Objek dalam penelitian adalah karakteristik tujuan anggaran, transparansi, kinerja anggaran dan kinerja manajerial. Variabel independen terdiri atas budgetary goal characteristics (X1) merupakan kriteria anggaran yang perlu diperhatikan untuk pencapaian tujuan anggaran, diukur menggunakan instrumen Munawar (2006); transparansi (X2) adalah keterbukaan pemerintah dalam memberikan informasi yang terkait dengan aktifitas pengelolaan sumber daya publik kepada pihak yang membutuhkan yaitu masyarakat, diukur dengan menggunakan instrumen Siregar (2011). 
Variabel dependen dalam penelitian ini adalah kinerja anggaran (Y1) yang didefinisikan sebagai sistem penganggaran yang berorientasi pada output organisasi dan berkaitan sangat erat dengan visi, misi, dan rencana organisasi, diukur dengan menggunakan instrumen Damaianti (2014); kinerja manajerial (Y2) adalah hasil secara periodik operasional suatu manajer berdasarkan sasaran, standar, dan kriteria yang telah ditetapkan sebelumnya, diukur dengan menggunakan instrumen dari Mahoney et.al (1963).

Populasi dalam penelitian ini adalah seluruh PNS maupun honorer dan pejabat struktural (meliputi kepala dinas, sekretaris, kepala bidang, kepala seksi, ataupun kasubag) pada instansi DPKPP Kota Denpasar. Teknik penentuan sampel yang digunakan adalah purposive sampling merupakan teknik penentuan sampel dengan kriteria tertentu (Sugiyono, 2008:122). Kriteria yang digunakan adalah pejabat struktural yang bertanggungjawab atas kinerja anggaran dan kinerja manajerial, staf PNS maupun honorer yang terlibat dalam proses anggaran dan terlibat dalam kinerja manajerial. Berdasarkan atas kriteria maka sampel yang digunakan yaitu sebanyak 51 orang.

Teknik pengumpulan data dengan mengajukan kuesioner kepada masing-masing responden. Teknik analisis data dalam penelitian ini menggunakan analisis kuantitatif yaitu dengan uji persamaan struktural berbasis variance atau yang lebih dikenal dengan nama Partial Least Square (PLS) menggunakan program WarpPLS. Uji kecocokan model melalui pendekatan PLS terdiri dari dua jenis, yaitu uji kecocokan model pengukuran (outer model) yang dievaluasi dengan nilai convergent validity dan discriminant validity serta uji kecocokan model struktural (inner model) dengan menilai R-square, path coefficient dan p-value. 


\section{HASIL DAN PEMBAHASAN}

Pengujian Model Pengukuran (Outer Model)

Tabel 1. Hasil Pengujian Model

\begin{tabular}{lcllll}
\hline & AVE & $\begin{array}{l}\text { Composite } \\
\text { Reliability }\end{array}$ & $\begin{array}{c}\text { Cronbach's } \\
\text { Alpha } \\
\text { Coefficients }\end{array}$ & VIFs & Rsquare \\
\hline $\begin{array}{l}\text { Karakteristik } \\
\text { Tujuan Anggaran }\end{array}$ & 0,729 & 0,844 & 0,629 & 1,348 & \\
$\begin{array}{l}\text { Transparansi } \\
\text { Kinerja }\end{array}$ & 0,703 & 0,877 & 0,788 & 1,549 & \\
$\begin{array}{l}\text { Anggaran } \\
\text { Kinerja }\end{array}$ & 0,709 & 0,830 & 0,589 & 1,395 & 0,229 \\
Manajerial & 0,687 & 0,897 & 0,846 & 1,182 & 0,004 \\
\hline Sumber: Data & & & & &
\end{tabular}

Sumber : Data diolah,2018

Convergent validity digunakan untuk mengetahui hubungan korelasi dari component score dengan construct score. Berdasarkan Tabel 1 menunjukkan nilai Cronbachs Alpha bernilai 0,6 - 0,8 menunjukkan hubungan korelasi dari component score dengan construct score. Discriminant validity dilihat berdasarkan nilai Average Variance Extracted (AVE), untuk memastikan bahwa setiap konsep dari masing-masing variabel laten berbeda dengan variabel lainnya. Nilai AVE dari masing-masing variabel bernilai lebih besar dari 0,5 berarti variabel yang digunakan telah memenuhi kriteria yang direkomendasikan. Nilai Composite Reliability yang lebih besar dari 0,70 berarti nilai variabel telah memenuhi kriteria yang direkomendasikan dan mencerminkan nilai reliabilitas semua indicator (Latan dan Ghozali, 2012:38).

\section{Pengujian Model Struktural (Inner Model)}

Pengujian inner model atau model struktural dilakukan untuk melihat hubungan antara variabel yaitu $R$-square untuk variabel laten endogen, koefisien parameter dan uji statistik $\mathrm{t}$ dari model penelitian. Model struktural dievaluasi dengan menggunakan $R$ square untuk konstruk dependen uji t serta signifikansi dari koefisien parameter jalur 
struktural. Adapun hubungan dari masing-masing variabel digambarkan dalam model struktural sebagai berikut:

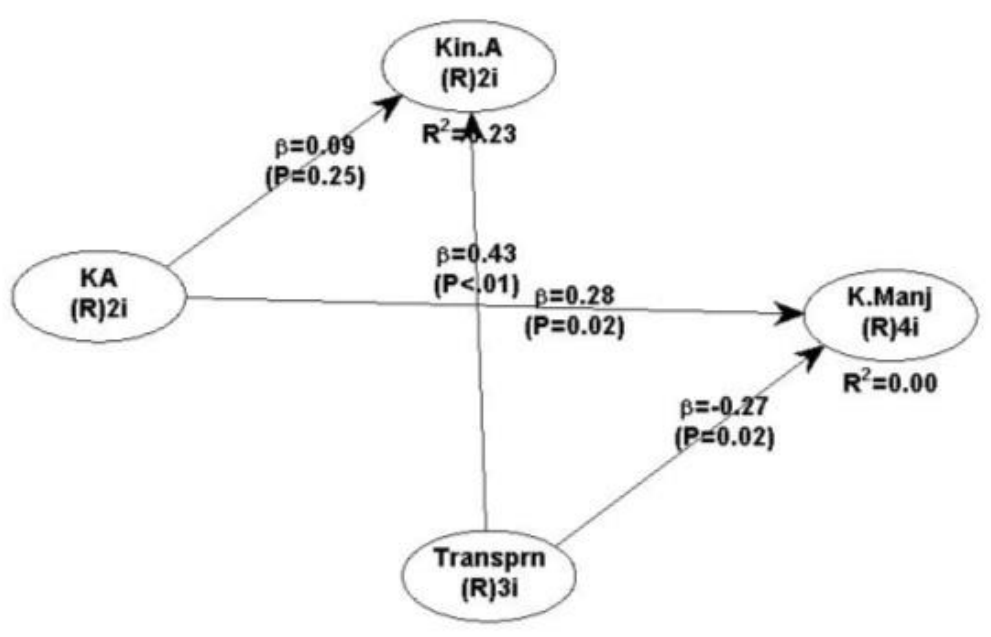

\section{Gambar 1. Model Struktural}

Berdasarkan Gambar 1 dan hasil output nilai $\mathrm{R}$ square untuk kinerja anggaran sebesar 0,229 yang memiliki arti bahwa 22,9\% variabel kinerja anggaran dipengaruhi oleh variabel karakteristik tujuan anggaran dan transparansi, sedangkan sisanya sebesar 77,1\% dipengaruhi oleh variabel lain di luar model penelitian ini. Nilai R square untuk kinerja manajerial sebesar 0,004 yang memiliki arti bahwa 4\% variabel kinerja manajerial dipengaruhi oleh variabel karakteristik tujuan anggaran dan transparansi, sedangkan sisanya sebesar $96 \%$ dipengaruhi oleh variabel lain di luar model penelitian ini.

Nilai path coefficient dan $\mathrm{p}$ values variabel karakteristik tujuan anggaran terhadap kinerja anggaran sebesar 0,091 dan 0,252 > 0,05 berarti karakteristik tujuan anggaran tidak berpengaruh pada kinerja anggaran. Hasil dari penelitian ini tidak mendukung penelitian dari Agusti (2012), Lismawati dan Auditya. (2013) dan Satya (2013). Hal ini mungkin disebabkan karena adanya partisipasi semu dalam proses penganggaran sehingga motivasi 
untuk pencapaian kinerja anggaran tidak tercapai dengan optimal. Tidak dapat dipungkiri bahwa proses penganggaran pada organisasi pemerintahan berbeda dengan sektor privat sehingga kemungkinan identifikasi karakteristik tujuan anggaran sulit dicapai. Berdasarkan hal tersebut dapat disimpulkan bahwa hasil penelitian ini menolak hipotesis pertama.

Nilai path coefficient dan $\mathrm{p}$ values variabel karakteristik tujuan anggaran terhadap kinerja manajerial sebesar 0,278 dan $0,016<0,05$ berarti karakteristik tujuan anggaran berpengaruh positif signifikan pada kinerja manajerial. Hasil penelitian ini membuktikan bahwa karakteristik tujuan anggaran berpengaruh positif terhadap kinerja manajerial, mendukung penelitian dari Munawar, dkk. (2006), Agusti (2012) dan Khotimah (2011). Dalam hal ini peningkatan kinerja manajerial DPKPP Kota Denpasar dipengaruhi oleh peningkatan penerapan karakteristik tujuan anggaran. Berdasarkan hal tersebut dapat disimpulkan bahwa hasil penelitian ini menerima hipotesis kedua.

Nilai path coefficient dan $p$ values variabel transparansi terhadap kinerja anggaran sebesar 0,432 dan 0,001 $<0,05$ berarti transparansi berpengaruh positif signifikan pada kinerja anggaran. Hasil dari penelitian ini membuktikan bahwa transparansi berpengaruh positif terhadap kinerja anggaran, mendukung penelitian dari Rahmawati (2013), Anugriani (2014) dan Wandari, dkk. (2015) karena transparansi (keterbukaan) dalam penganggaran dapat meningkatkan kinerja anggaran untuk menghasilkan anggaran yang diharapkan. Transparansi akan mempengaruhi kinerja anggaran karena kinerja anggaran akan semakin jelas arah realisasinya dan pelaporan atas kinerja anggaran akan memberikan dampak positif terhadap kinerja aparat pemerintah dalam menjalankan anggaran. Berdasarkan hal tersebut dapat disimpulkan bahwa hasil penelitian ini menerima hipotesis ketiga. 
Nilai path coefficient dan p values variabel transparansi terhadap kinerja manajerial sebesar $-0,271$ dan $0,018<0,05$ berarti transparansi berpengaruh negatif pada kinerja manajerial. Hasil penelitian ini berlawanan dengan hasil penelitian Aji (2011) dan Lismawati dan Auditya. (2013), yang menunjukkan bahwa peningkatan transparansi dapat menurunkan kinerja manajerial DPKPP Kota Denpasar. Hal ini mungkin disebabkan karena adanya dampak yang berbeda yang ditimbulkan oleh pelaksanaan transparansi. Dalam konteks tertentu, transparansi memang meningkatkan kinerja, namun hal itu tidak selalu terjadi. Penerapan transparansi bisa jadi menimbulkan kecemasan yang berlebih dalam perilaku aparat pemerintah, misalnya dalam proses pengambilan keputusan sehingga malah menurunkan kinerja manajerialnya. Berdasarkan hal tersebut dapat disimpulkan bahwa hasil penelitian ini menolak hipotesis keempat.

\section{SIMPULAN DAN SARAN}

Berdasarkan hasil analisis, maka dapat diperoleh simpulan bahwa karakteristik tujuan anggaran tidak berpengaruh terhadap kinerja anggaran, karakteristik tujuan anggaran berpengaruh positif terhadap kinerja manajerial dan transparansi berpengaruh positif terhadap kinerja anggaran, sedangkan transparansi berpengaruh negatif terhadap kinerja manajerial pada DPKPP Kota Denpasar.

Penelitian ini hanya menggunakan dua variabel independent yaitu karakteristik tujuan anggaran dan transparansi, terbatas hanya pada DPKPP Kota Denpasar. Dengan demikian penelitian selanjutnya diharapkan dapat memasukkan faktor-faktor lain yang dapat mempengaruhi kinerja anggaran dan kinerja manajerial untuk diteliti lebih lanjut seperti akuntabilitas, pengawasan internal, dan motivasi. Penelitian selanjutnya juga diharapkan meneliti di instansi-instansi yang ada pada suatu daerah agar mengetahui lebih luas bagaimana kinerja sumber daya manusia yang ada pada sektor pemerintahan. 
Pengumpulan data pada penelitian selanjutnya diharapkan tidak hanya terbatas pada penyebaran kuisioner saja tetapi dapat pula dilakukan melalui wawancara sehingga responden dapat menanyakan secara langsung mengenai item pertanyaan yang kurang dipahami.

\section{DAFTAR PUSTAKA}

Agusti, Restu. 2012. Pengaruh Partisipasi Penyusunan Anggaran Terhadap Kinerja Aparatur Pemerintah Daerah Dengan Dimoderasi Oleh Variabel Desentralisasi dan Budaya Organisasi (Studi Kasus Pada Pemerintah Kabupaten Bengkalis. Jurnal Ekonomi Vol.20 No.3 September 2012. Universitas Riau.

Aji, Fakih Sabdanala. 2011. Pengaruh Akuntabilitas Publik, Partisipasi Penyusunan Anggaran dan Transparansi Kebijakan Publik Terhadap Kinerja Manajerial Pada Satuan Kerja Perangkat Daerah (SKPD) se-Kabupaten Wonosobo. Skripsi. Universitas Negeri Semarang.

Anugriani, Mulya. 2014. Pengaruh Akuntabilitas, Transparansi, dan Pengawasan terhadap Kinerja Anggaran Berkonsep Value for Money pada Instansi Pemerintah di Kabupaten Bone. Skripsi. Universitas Hasanudin, Makasar.

Bastian, Indra. 2006. Sistem Akuntansi Sektor Publik. Jakarta: Salemba Empat.

Damaianti, Indriana 2014. Evaluasi Penerapan Anggaran Berbais Kinerja Di Pemerintah Kota Bandung. Skripsi. Universitas Widyatama Bandung.

Departemen Keuangan Republik Indonesia/ Badan Pendidikan dan Pelatihan Keuangan (BPPK). 2008. Kajian Terhadap Penerapan Penganggaran Berbasis Kinerja di Indonesia.

Istiyani. 2009. Pengaruh Karakteristik Tujuan Anggaran Terhadap Kinerja Aparat Pemerintah Daerah (Studi Empiris Pada Pemerintah Kabupaten Temanggung). Tesis. Universitas Sebelas Maret Sukarta.

Jensen, Michael C. dan Meckling, William. 1976. Theory of The Firm, Managerial Behavior, Agency and Ownership Structure. Journal of Financial Economics.

Kenis, Izzettin. 1979. Effects of Budgetary Goal Characteristics on Managerial Attitudes and Performance. The Accounting Review. LIV.2. Hal 707-721.

Khotimah, Siti. 2011. Pengaruh Karakteristik Tujuan Anggaran Terhadap Kinerja Manajerial Pada Satuan Kerja Perangkat Daerah (SKPD) di Kabupaten Blora Dengan Komitmen Organisasi Sebagai Variabel Moderating. Skripsi. Universitas Negeri Semarang. 
Latan, Hengky dan Ghozali, Imam. 2012. PLS Konsep, Metode dan Aplikasi Menggunakan Program Warp PLS 2.0 untuk Penelitian Empiris. Semarang: BPFE Universitas Diponegoro.

Lismawati, Husain dan Auditya, Lucy. 2013. Analisis Pengaruh Akuntabilitas dan Transparansi Pengelolaan Keuangan Daerah Terhadap Kinerja Pemerintah Daerah. Jurnal Fairness Volume 3, Nomor 1, 2013: 21-24. Universitas Bengkulu.

Mahoney, T.A., T. H. Jerdee \& S.J. Carroll. 1963. Development Of Manajerial Performance: A Research Approach. Cincinnti: South Western Publishing.

Mardiasmo. 2009. Akuntansi Sektor Publik. Yogyakarta : Penerbit Andi.

Milayanti, Mia dan Kholmi, Masiyah. 2012. Pengaruh Budgetary Goal Characteristics Terhadap Sikap Aparat Dalam Menilai Kinerja Pemerintah Daerah; Studi pada Satuan Kerja Perangkat Daerah Kota Palangkaraya. Jurnal Reviu Akuntansi dan Keuangan, Vol. 2, No. 1, April 2012, pp. 243-250.

Munawar., Irianto, Gugus., Nurkholis. 2006. Pengaruh Karakteristik Tujuan Anggaran Terhadap Perilaku, Sikap, dan Kinerja Aparat Pemerintah Daerah Di Kabupaten Kupang. Simposium Nasional Akuntansi 9 Padang.

Rahmawati, Arini Ayu. 2013. Pengaruh Partisipasi Masyarakat dan Transparansi Terhadap Pengawasan Keuangan Daerah Di Kabupaten Sukoharjo. Skripsi. Universitas Muhammadiyah Surakarta.

Satya, Swahdhika Purwa. 2013. Pengaruh Partisipasi Staf, Motivasi dan Pelimpahan Wewenang Terhadap Penyusunan Rencana Anggaran. Skripsi. Universitas Mahasaraswati Denpasar.

Sesotyaningtyas, Mirna. 2012. Pengaruh Leverage, Ukuran Legislatif, dan Ingovernmental revenue Terhadap Kinerja Keuangan Pemerintah Daerah Studi Empiris pada Pemerintah Daerah Kabupaten/Kota di Jawa. Skripsi. Semarang: Unnes.

Siregar, Liper. 2011. Pengaruh Akuntabilitas Publik, Transparansi Publik dan Pengawasan Terhadap Pengelolaan APBD Dengan Standar Akuntansi Pemerintah Sebagai Variabel Moderator Pada Pemerintah Kota Pematangsiantar. Tesis. Universitas Sumatera Utara, Medan.

Sugiyono. 2008. Metodologi Penelitian Bisnis. Bandung. Alfabeta.

Wandari, I Desak Nyoman Tri., Sujana, Edy dan Adi Putra, I Made Pradana. 2015. Pengaruh Akuntanbilitas, Transparansi, Ketepatan Waktu dan Pengawasan Internal Terhadap Kinerja Anggaran Berkonsep Value For Money Pada Instansi Pemerintah Di Kabupaten Buleleng. Skripsi. Universitas Pendidikan Ganesha. 